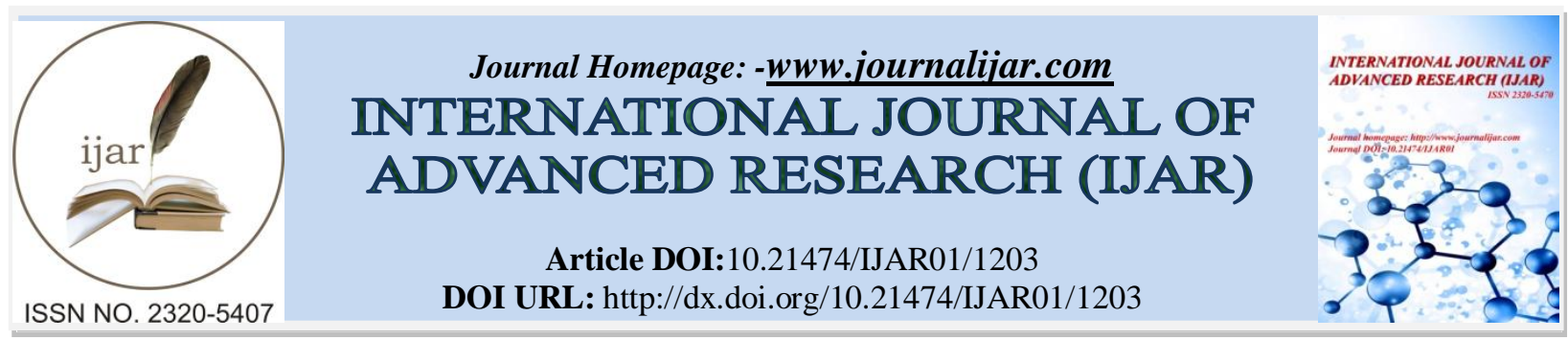

RESEARCH ARTICLE

\title{
ANALYSIS OF NUTRITIONAL COMPOSITION AND ANTI-NUTRITIONAL FACTORS OF FRESH KARMWA LEAVES (IPOMOEA AQUATICA) AND ITS PRODUCTS DEVELOPMENT.
}

\section{Anisha Verma ${ }^{1}$, Neerubala ${ }^{2}$ and Bhawna Srivastava ${ }^{3}$.}

1. AssistantProfessor,Department of Foods and Nutrition, Ethelind School of Home Science, Sam Higginbottom Institute of Agriculture, Technology and Sciences, Allahabad- 211007, (U.P.)

2. Associate Professor ,Department of Foods and Nutrition, Ethelind School of Home Science, Sam Higginbottom Institute of Agriculture, Technology and Sciences, Allahabad- 211007, (U.P.)

3. JRF,Department of Foods and Nutrition, Ethelind School of Home Science, Sam Higginbottom Institute of Agriculture, Technology and Sciences, Allahabad- 211007, (U.P.)

\section{Manuscript Info}

\section{Manuscript History}

Received: 16 June 2016

Final Accepted: 19 July 2016

Published: August 2016

Key words:-

Underutilized vegetables, Nutritional composition, Sensory acceptability,

Conventional food products

\section{Abstract}

\begin{abstract}
Water Spinach is scientifically known as Ipomoea aquatica, is a popular ingredient in various cuisines such as desserts and salads and it is often eaten raw because of its deliciously sweet taste. It can be steam and boiled, just like regular spinach. The aim of the study is to find out the nutritional and anti-nutritional composition of the water spinach to prepare value added products with the incorporation of Water Spinach and to evaluate the sensory acceptability of the prepared products. Methods described by AOAC (2005) were used for the determination of nutritional and anti-nutritional composition of karamwa leaves. Leaves of Karamwa were incorporated into six conventional food products namely Roti, Daal, Khichadi, BesanChakali, Vegetable crispy ball (Vegetable Pakoda) and Mathari at the level of 40, 60 and 80 percent into the various recipes. The formulated products were subjected to sensory analysis by panel members with the help of nine point hedonic scale. In $100 \mathrm{~g}$ of fresh karamwa leaves energy was $36 \mathrm{Kcal}$, ash $6.92 \mathrm{~g}$, Moisture $85.11 \%$, total carbohydrate $3.98 \mathrm{~g}$, protein $3.2 \mathrm{~g}$, fat $0.8 \mathrm{~g}, \beta$ - Carotene $298 \mu \mathrm{g}$, iron $4.3 \mathrm{mg}$, oxalic acid $125 \mathrm{mg}$, phytate $75 \mathrm{mg}$. Result showed that the incorporation of Karmwa leaves in Roti, Daal, Khichadi, BesanChakali, Vegetable crispy ball (Vegetable Pakoda) and Mathari was most acceptable with 60 percent followed by 40 and 80 percent. Hence it is concluded that Leaves of Karamwa, can be successfully incorporated into different conventional food products and are helpful in improving nutrients content of developed recipes.
\end{abstract}

Copy Right, IJAR, 2016,. All rights reserved.

\section{Introduction:-}

Water Spinach (Ipomoea aquatica) is a semi-aquatic, tropical plant grown as a vegetable for its tender shoots and leaves. It is found throughout the tropical and subtropical regions of the world, although it is not known where it 
originated. This plant is known in English as water spinach, river spinach, water morning glory, water convolvulus, or by the more ambiguous names Chinese spinach, Chinese Watercress, Chinese convolvulus, swamp cabbage or kangkong in Southeast Asia.Occasionally, it has also been mistakenly called "kale" in English, although kale is a strain of mustard belonging to the species Brassica oleracea and is completely unrelated to water spinach, which is a species of morning glory.

(https://en.wikipedia.org/wiki/Ipomoea_aquatica)

The leaves of water spinach are extremely nutritious, containing abundant quantities of vitamins and minerals. They are excellent sources of dietary fiber, protein, calcium, iron, vitamin A and vitamin C.

The present study was aimed to analyze the nutritional composition, anti-nutritional factors of the Karamwa (Ipomoea aquatica) leaves to prepare value added products using Karamwa (Ipomoea aquatica) leaves and to evaluate the sensory acceptability of the prepared products.

\section{Methodology:-}

The present investigation was conducted in the Nutrition Research Laboratory, Department of Foods and Nutrition, Ethelind School of Home Science, Sam Higginbottom Institute of Agriculture, Technology and Sciences (Deemed to be University), Allahabad, U.P. In order to determine the nutritional and anti-nutritional characteristics of Karamwa (Ipomoea aquatica) leaves, standard methods described below as follows-:

\section{Procurement of raw materials:-}

Karamwa (Ipomoea aquatica) leaves were procured from local areas of SHIATS, Allahabad, India and other raw materials were collected from the local market of Allahabad.

\section{Determination of nutrients and anti-nutrients content of selected underutilized green leafy vegetables:-}

Nutrients and anti-nutrients estimation of Karamwa leaves for moisture, ash, protein, fat, carbohydrate, $\beta$-Carotene, iron, phytate and oxalate content were analysed using standard procedures of AOAC (2005).

\section{Products development:-}

Karamwa (Ipomoea aquatica) leaves were used for the development of value added locally familiar food products namely Roti, Daal, Khichadi, BesanChakali, Vegetable crispy ball (Vegetable Pakoda) and Mathari at the incorporation level of 40,60 and 80 percent incorporation. The basic recipe was standardized and served as control $\left(\mathrm{T}_{0}\right)$. Three value added treatments i.e. incorporation with Karamwa (Ipomoea aquatica) leaves at 40 percent, 60 percent, and 80 percent levels were referred to as $T_{1}, T_{2}$ and $T_{3}$ respectively for each of the six products developed. All the controls and treatments for all products were replicated three times.

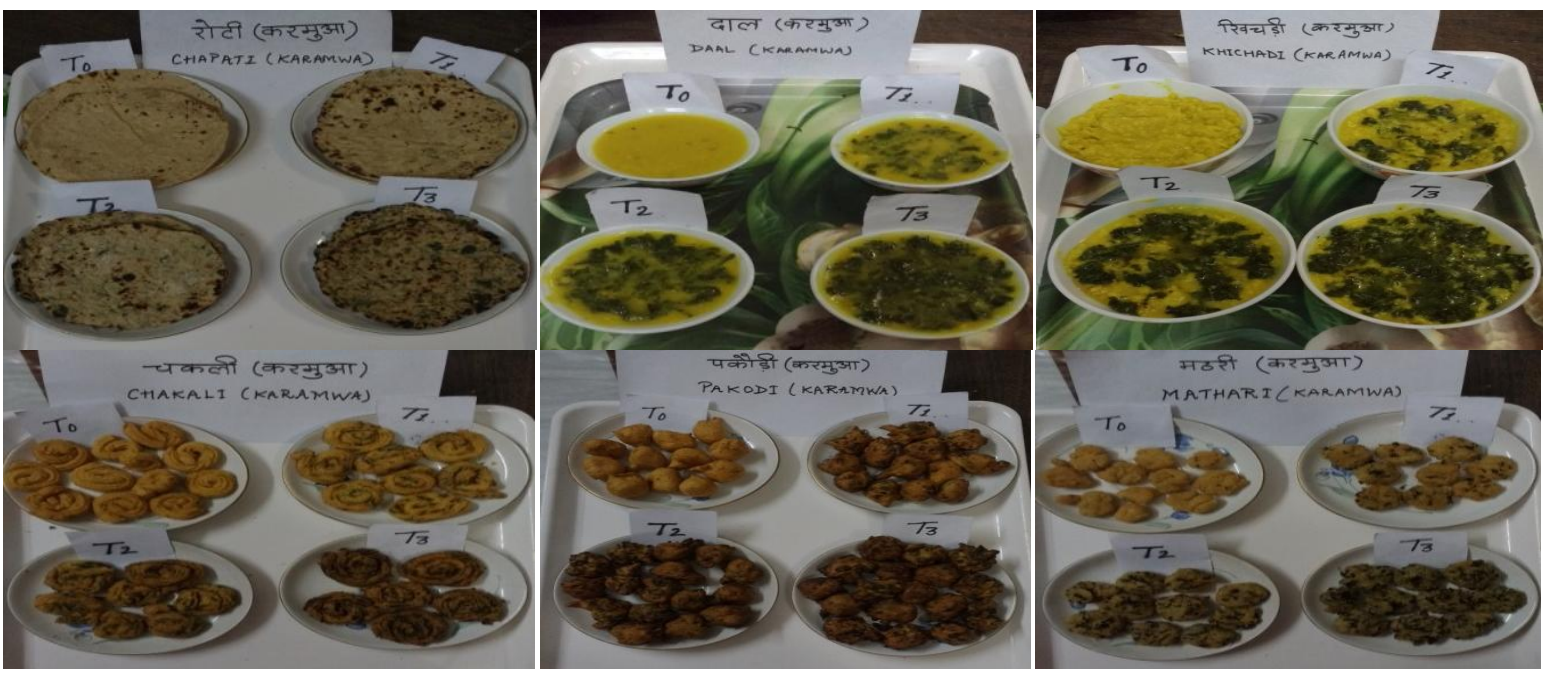

Fig 1:-Products developed by incorporating Karamwa (Ipomoea aquatica) leaves. 


\section{Organoleptic evaluation of the prepared products:-}

The organoleptic evaluation of prepared products was done by a panel of 5 judges to assess the acceptability of the products. The evaluation was done on the 9 point Hedonic scale based score card (Srilakhmi, 2007).

\section{Statistical Analysis:-}

Data obtained from the organoleptic evaluation was analyzed using Analysis of Variance and Critical Difference Techniques (Gupta and Kapoor 2002).

\section{Results and discussion:-}

The data collected on different aspects as per the methodology have been tabulated and analyzed statistically. The results obtained from the analysis are presented and discussed as follows.

\section{Chemical Analysis of fresh Kramwa leaves:-}

Results shows (Table-1) that the Nutrients in fresh Karamwa leaves per $100 \mathrm{~g}$ are found, Energy $36 \mathrm{Kcal}$, Moisture $85.11 \%$, Ash $6.92 \mathrm{~g}$, Protein 3.2g, Total Carbohydrate $3.98 \mathrm{~g}$, Fat 0.8g, Iron $4.3 \mathrm{mg}, \beta$ - Carotene $298 \mu \mathrm{g}$. Oxalate and phytate content in fresh Karamwa (Ipomoea aquatica) leaves per $100 \mathrm{~g}$ are found $125 \mathrm{mg}$ and $75 \mathrm{mg}$ respectively.

Sensory analysis of products prepared by incorporation of fresh Karamwa (Ipomoea aquatica) leaves:-

The products were standardized and subjected to organoleptic evaluation within one hour of preparation which was considered as zero days. All experimental recipes were evaluated in terms of colour and appearance, body and texture, taste and flavor and overall acceptability.

Table 1:- Nutrients and anti-nutrients content of fresh Karamwa (Ipomoea aquatica) leaves per 100g

\begin{tabular}{|l|l|}
\hline Nutrients & Lehsua leaves per100 g \\
\hline Energy & $36 \mathrm{Kcal}$ \\
\hline Moisture & $85.11 \%$ \\
\hline Ash & $6.92 \mathrm{~g}$ \\
\hline Protein & $3.2 \mathrm{~g}$ \\
\hline Total Carbohydrate & $3.98 \mathrm{~g}$ \\
\hline Fat & $0.8 \mathrm{~g}$ \\
\hline Iron & $4.3 \mathrm{mg}$ \\
\hline$\beta$ - Carotene & $298 \mu \mathrm{g}$ \\
\hline Oxalic Acid & $125 \mathrm{mg}$ \\
\hline Phytate & $75 \mathrm{mg}$ \\
\hline
\end{tabular}

\section{Sensory score of Roti:-}

It can be seen from table- 2 that sensory scores of Roti with incorporation of fresh Karamwa Leaves; the colour and appearance was highest in $T_{1}(8)$ followed by $T_{2}(7)$, control $T_{0}(7)$ and $T_{3}(6)$ and body and texture was highest in treatment $\mathrm{T}_{2}(8)$ followed by $\mathrm{T}_{1}(7), \mathrm{T}_{3}(7)$ and control $\mathrm{T}_{0}(6)$. The taste and flavour was highest in $\mathrm{T}_{2}(8)$ followed by $\mathrm{T}_{3}(7), \mathrm{T}_{1}(7)$ and control $\mathrm{T}_{0}(7)$ and overall acceptability was highest in $\mathrm{T}_{2}(8)$ followed by control $\mathrm{T}_{0}(7), \mathrm{T}_{1}(7)$ and $\mathrm{T}_{3}$ (7). The significant difference was found between the control and treatments of Roti indicating that the addition of 60 percent fresh Karamwa Leaves improves the taste and flavour of the Roti.

Table 2:- Sensory analysis of Roti prepared by incorporation of fresh Karamwa (Ipomoea aquatica) leaves.

\begin{tabular}{|l|l|l|l|l|}
\hline Parameters & $\mathbf{T}_{\mathbf{0}}$ & $\mathbf{T}_{\mathbf{1}}$ & $\mathbf{T}_{\mathbf{2}}$ & $\mathbf{T}_{\mathbf{3}}$ \\
\hline Colour and Appearance & 7 & 8 & 7 & 6 \\
\hline Body and Texture & 6 & 7 & 8 & 7 \\
\hline Taste and Flavour & 7 & 7 & 8 & 7 \\
\hline Overall Acceptability & 7 & 7 & 8 & 7 \\
\hline
\end{tabular}

\section{Sensory score of Daal:-}

It can be seen from table-3 that sensory scores of Daalwith incorporation of fresh Karamwa Leaves; the colour and appearance was highest in $T_{2}(8)$ followed by $T_{1}(7)$, control $T_{0}(7)$ and $T_{3}(6)$ and body and texture was highest in $T_{2}$ (8) followed by $T_{1}(7)$, control $T_{0}(7)$ and $T_{3}(6)$. The taste and flavour was highest in $T_{2}(8)$ followed by $T_{1}(7)$, control $\mathrm{T}_{0}(7)$ and $\mathrm{T}_{3}(6)$ and overall acceptability was highest in $\mathrm{T}_{2}(8)$ followed by $\mathrm{T}_{1}(7)$, control $\mathrm{T}_{0}(7)$ and $\mathrm{T}_{3}(6)$. 
The significant difference was found between the control and treatments of taste and flavour indicating that the addition of 60 percent fresh Karamwa Leaves improves the sensory acceptability of the Daal.

Table 3:-Sensory analysis of Daal prepared by incorporation of fresh Karamwa (Ipomoea aquatica) leaves.

\begin{tabular}{|l|l|l|l|l|}
\hline Parameters & $\mathbf{T}_{\mathbf{0}}$ & $\mathbf{T}_{\mathbf{1}}$ & $\mathbf{T}_{\mathbf{2}}$ & $\mathbf{T}_{\mathbf{3}}$ \\
\hline Colour and Appearance & 7 & 7 & 8 & 6 \\
\hline Body and Texture & 7 & 7 & 8 & 6 \\
\hline Taste and Flavour & 7 & 7 & 8 & 6 \\
\hline Overall Acceptability & 7 & 7 & 8 & 6 \\
\hline
\end{tabular}

\section{Sensory score of Khichadi:-}

It can be seen from table-4 that sensory scores of Khichadi with incorporation of fresh Karamwa Leaves; the colour and appearance was highest in $\mathrm{T}_{2}(8)$ followed by control $\mathrm{T}_{0}(7), \mathrm{T}_{1}(7)$, and $\mathrm{T}_{3}(6)$ and body and texture was highest in control $\mathrm{T}_{2}(8)$ followed by $\mathrm{T}_{0}(8), \mathrm{T}_{1}(7)$, and $\mathrm{T}_{3}(6)$. The taste and flavour was highest in $\mathrm{T}_{2}(8)$ followed by $\mathrm{T}_{1}(8)$, control $\mathrm{T}_{0}(7)$, and $\mathrm{T}_{3}(7)$ and overall acceptability was highest in control $\mathrm{T}_{2}(8)$ followed by $\mathrm{T}_{1}(7), \mathrm{T}_{0}(7)$ and $\mathrm{T}_{3}(6)$. The significant difference was found between the control and treatments of taste and flavour indicating that the addition of 60 percent fresh Karamwa Leaves improves the taste and flavour of the Khichadi.

Table 4:-Sensory analysis of Khichadi prepared by incorporation of fresh Karamwa (Ipomoea aquatica) leaves.

\begin{tabular}{|l|l|l|l|l|}
\hline Parameters & $\mathbf{T}_{\mathbf{0}}$ & $\mathbf{T}_{\mathbf{1}}$ & $\mathbf{T}_{\mathbf{2}}$ & $\mathbf{T}_{\mathbf{3}}$ \\
\hline Colour and Appearance & 7 & 7 & 8 & 6 \\
\hline Body and Texture & 8 & 7 & 8 & 6 \\
\hline Taste and Flavour & 7 & 8 & 8 & 7 \\
\hline Overall Acceptability & 7 & 7 & 8 & 7 \\
\hline
\end{tabular}

\section{Sensory score of besanchakali:-}

It can be seen from table-5 that sensory scores of BesanChakali with incorporation of fresh Karamwa Leaves; the colour and appearance was highest in $\mathrm{T}_{2}(8)$ followed by control $\mathrm{T}_{0}(7), \mathrm{T}_{1}(7)$ and $\mathrm{T}_{3}(6)$ and body and texture was highest in control $\mathrm{T}_{2}(8)$ followed by $\mathrm{T}_{0}(7), \mathrm{T}_{1}(7)$ and $\mathrm{T}_{3}(6)$. The taste and flavour was highest in $\mathrm{T}_{2}(8)$ followed by control $\mathrm{T}_{1}(8), \mathrm{T}_{3}(7)$ and $\mathrm{T}_{0}(7)$ and overall acceptability was highest in control $\mathrm{T}_{2}(8)$ followed by $\mathrm{T}_{1}(7), \mathrm{T}_{0}(7)$ and $\mathrm{T}_{3}(6)$. The significant difference was found between the control and treatments of taste and flavour indicating that the addition of fresh Karamwa Leaves improves the taste and flavour of the BesanChakali.

Table 5:-Sensory analysis of BesanChakali prepared by incorporation of fresh Karamwa (Ipomoea aquatica) leaves

\begin{tabular}{|l|l|l|l|l|}
\hline Parameters & $\mathbf{T}_{\mathbf{0}}$ & $\mathbf{T}_{\mathbf{1}}$ & $\mathbf{T}_{\mathbf{2}}$ & $\mathbf{T}_{\mathbf{3}}$ \\
\hline Colour and Appearance & 7 & 7 & 8 & 6 \\
\hline Body and Texture & 7 & 7 & 8 & 6 \\
\hline Taste and Flavour & 7 & 8 & 8 & 7 \\
\hline Overall Acceptability & 7 & 7 & 8 & 6 \\
\hline
\end{tabular}

\section{Sensory score of vegetable crispy balls (vegetable pakoda):-}

It can be seen from table 6 that sensory scores of vegetable pakodawith incorporation fresh Karamwa Leaves; the colour and appearance was highest in $\mathrm{T}_{2}(8)$ followed by control $\mathrm{T}_{0}(8), \mathrm{T}_{1}(7), \mathrm{T}_{3}(7)$ and body and texture was highest in treatment $\mathrm{T}_{2}(8)$ followed by $\mathrm{T}_{1}(7), \mathrm{T}_{3}(7)$ and control $\mathrm{T}_{0}(6)$. The taste and flavour was highest in control $\mathrm{T}_{0}(8)$ followed by $\mathrm{T}_{2}(7), \mathrm{T}_{1}(7)$ and $\mathrm{T}_{3}(6)$ and overall acceptability was highest in $\mathrm{T}_{2}(8)$ followed by control $\mathrm{T}_{0}(7)$, $\mathrm{T}_{1}$ (7) and $\mathrm{T}_{3}(7)$. The significant difference was found between the control and treatments of taste and flavour indicating that the addition of fresh Karamwa Leaves improves the taste and flavour of the Besancheela. 
Table 6:- Sensory analysis of BesanCheela prepared by incorporation of fresh Karamwa (Ipomoea aquatica) leaves.

\begin{tabular}{|l|l|l|l|l|}
\hline Parameters & $\mathbf{T}_{\mathbf{0}}$ & $\mathbf{T}_{\mathbf{1}}$ & $\mathbf{T}_{\mathbf{2}}$ & $\mathbf{T}_{\mathbf{3}}$ \\
\hline Colour and Appearance & 8 & 7 & 8 & 7 \\
\hline Body and Texture & 6 & 7 & 8 & 7 \\
\hline Taste and Flavour & 8 & 7 & 7 & 6 \\
\hline Overall Acceptability & 7 & 7 & 8 & 7 \\
\hline
\end{tabular}

Sensory score of mathari:-

It can be seen from table 7 that sensory scores of Mathari with the incorporation fresh Karamwa Leaves; colour and appearance was highest in $T_{2}(8)$ followed by $T_{3}(8)$, control $T_{0}(7)$ and $T_{1}(7)$ and body and texture was highest in $T_{2}$ (8) followed by $T_{1}(7)$, control $T_{0}(7)$ and $T_{3}(7)$. The taste and flavour was highest in $T_{2}(8)$ followed by $T_{1}(8)$, control $\mathrm{T}_{0}(7)$ and $\mathrm{T}_{3}(7)$ and overall acceptability was highest in $\mathrm{T}_{2}(8)$ followed by control $\mathrm{T}_{0}(7), \mathrm{T}_{1}(7)$ and $\mathrm{T}_{3}(7)$. The significant difference was found between the control and treatments of taste and flavour indicating that the addition of fresh Karamwa Leaves improves the taste and flavour of the Mathari.

Table 7:-Sensory analysis of Mathari prepared by incorporation of fresh Karamwa (Ipomoea aquatica) leaves.

\begin{tabular}{|l|l|l|l|l|}
\hline Parameters & $\mathbf{T}_{\mathbf{0}}$ & $\mathbf{T}_{\mathbf{1}}$ & $\mathbf{T}_{\mathbf{2}}$ & $\mathbf{T}_{\mathbf{3}}$ \\
\hline Colour and Appearance & 7 & 7 & 8 & 8 \\
\hline Body and Texture & 7 & 7 & 8 & 7 \\
\hline Taste and Flavour & 7 & 8 & 8 & 7 \\
\hline Overall Acceptability & 7 & 7 & 8 & 7 \\
\hline
\end{tabular}

Result showed that the incorporation of Karamwa leaves in Roti, Daal, Khichadi, BesanChakali, Vegetable Crispy Ball (Vegetable Pakoda) and Mathari was most acceptable with 60 percent followed by 40 and 80 percent.

\section{Conclusion:-}

From the results summarized above, it can be concluded that Karamwa leaves can be suitably incorporated in various traditional products. Nutrients in Karamwa Leaves per $100 \mathrm{~g}$ are found Energy $36 \mathrm{Kcal}$, Moisture 85.11\%, Ash 6.92g, Protein 3.2g, Total Carbohydrate 3.98g, Fat $0.8 \mathrm{~g}$, Iron $4.3 \mathrm{mg}$, $\beta$ - Carotene $298 \mu \mathrm{g}$, Oxalate $125 \mathrm{mg}$ and phytate $75 \mathrm{mg}$. Sensory scores of products prepared with the incorporation of Karamwa leaves i.e. Roti, Daal, Khichadi, BesanChakali, Vegetable Crispy Ball (Vegetable Pakoda) and Mathari were most acceptable with $60\left(\mathrm{~T}_{2}\right)$ percent followed by $40\left(\mathrm{~T}_{1}\right)$ and 80 percent $\left(\mathrm{T}_{3}\right)$. Karamwa Leaves is a good source of protein, ironand $\beta$-Carotene.

\section{References:-}

1. AOAC (2005), Officinal methods of Analysis. Fourteenth edition. Association of Official Analytical Chemists, Washington, DC.

2. Gupta, S. C. and Kapoor, U. K., (2002); "Fundamentals of Applied Statistics" $2^{\text {nd }}$ edition, Chand and Son, pp: 51-85.

3. Joshi Pallavi and MathurBeena (2010) Preparation of value added products from the leaf powders of dehydrated less utilized green leafy vegetables.Journal of Horticulture and Forestry. 2 (9) 223 - 228

4. Srilakshmi, B. (2007) Food Sciences" $5^{\text {th }}$ Edition New Age International Publishers 194-198. 